\section{Reversible dilated cardiomy- opathy: into the thaumaturgy of the heart - Part 2}

\author{
Giovanni Quarta, ${ }^{1}$ Raffaele Coppini, ${ }^{2}$ \\ Pier Lambiase, ${ }^{3}$ Pablo Garcia-Pavia, ${ }^{4}$ \\ Alice Calabrese, ${ }^{1}$ Anna Maria Iorio, ${ }^{1}$ \\ Niccolò Maurizi, ${ }^{5}$ Maria lascone, ${ }^{6}$ \\ Antonello Gavazzi, ${ }^{7}$ lacopo Olivotto, ${ }^{5}$ \\ Michele Senni ${ }^{1}$ \\ ${ }^{1}$ Cardiovascular Department, Papa \\ Giovanni XXIII Hospital, Bergamo, Italy; \\ 2Department of Preclinical and Clinical \\ Pharmacology and Center of Molecular \\ Medicine, University of Florence, \\ Florence, Italy; ${ }^{3}$ Institute of \\ Cardiovascular Science, University \\ College and Bart's Heart Centre, Bart's \\ Health NHS Trust, London, UK; ${ }^{4}$ Heart \\ Failure and Inherited Cardiac Diseases \\ Unit, Department of Cardiology, Puerta \\ de Hierro University-Hospital, Madrid, \\ Spain; ${ }^{5}$ Referral Center for \\ Cardiomyopathies, Careggi University- \\ Hospital, Florence, Italy; ${ }^{6}$ Medical \\ Genetics Lab, Papa Giovanni XXIII \\ Hospital, Bergamo, Italy; ${ }^{7}$ Research \\ Foundation (FROM), Papa Giovanni XXIII \\ Hospital, Bergamo, Italy
}

\section{Abstract}

Dilated cardiomyopathy (DCM) is a genetic or acquired heart muscle disorder characterized by dilation and impaired contraction of one or both ventricles. In the acquired forms of the disease, if the pathogenic agent is persistent, undiagnosed or untreated, permanent ultrastructural and morphological changes may lead to irreversible dysfunction. Conversely, when DCM is promptly recognized and treated, the heart may show an extraordinary ability to recover from left ventricular (LV) systolic dysfunction. While much research in heart failure has focused on morbidity and mortality associated with persistent LV systolic dysfunction, relatively little attention has been devoted to this remarkable potential for recovery. In this two-part review we will focus on the most common types of reversible DCM. The second part will deal with chemotherapy-induced cardiomyopathy, alcohol-related cardiomyopathy, myocarditis and peripartum cardiomyopathy. Although diverse in etiopathogenesis, genetic background, therapeutic options and outcome, the forms of DCM characterized by reversible LV dysfunction share similar challenges in diagnosis and clinical management. The identification of pathways to recovery may show the way for novel therapeutic targets ultimately benefitting all cardiac patients.

\section{Chemotherapy-induced cardiomyopathy}

Chemotherapy is a well-known cause of cardiomyopathy (Table 1) and the cardiac toxic effects of anthracyclines, prototypal in cardiooncology, have been investigated for more than 30 years. ${ }^{1}$ Although acute cardiotoxicity is possible, chronic cardiotoxicity is more common; its occurrence and severity are proportional to the cumulative dose (for example doxorubicin $>400-500 \mathrm{mg} / \mathrm{m}^{2}$ is associated with significant risk) and may become evident several years after exposure. Occasionally, the gap may be sufficiently long as to render the association between chemotherapy and cardiomyopathy counterintuitive. Serial echocardiographic assessment of left ventricular (LV) systolic function is commonly used to evaluate chemotherapy-induced cardiomyopathy, while cardiovascular magnetic resonance (CMR) is indicated as a second-line investigation when evident disease or borderline abnormalities are identified. ${ }^{2}$ Historically, cardiotoxicity is defined by a $\geq 5 \%$ decline in LV ejection fraction (LVEF) resulting in an LVEF $<55 \%$ with symptoms of heart failure, or a $10 \%$ decline to result in an LVEF $<55 \%$ without symptoms of heart failure, ${ }^{1,3}$ or $\geq 20 \%$ or $>15 \%$ LVEF decline from baseline, but remaining $\geq 50 \%$, or any LVEF decline to $<50 \%{ }^{4}$ Clinical manifestations vary from mild, subclinical systolic impairment to severe dilated cardiomyopathy and refractory heart failure. Today, about half of the patients surviving cancer die of cardiovascular complications of treatment. There are 2 major types of cardiotoxicity-type 1 and 2 . Type 1 (typical caused by anthracyclines) is associated with ultrastructural changes, poor prognosis and lower recovery rates. Type 2 cardiotoxicity (for example caused by trastuzumab), is not associated with histological changes and have better prognosis. ${ }^{5}$ Chemotherapy-induced cardiomyopathy represents $2.5 \%$ of all heart transplant recipients. ${ }^{6}$

Biomarkers such as troponin, natriuretic peptides, C-reactive proteins and others have been proposed as early markers of cardiotoxicity and are useful in predicting risk. Treatment is still empirical and mainly based on standard heart failure medications. Recovery of LV systolic function has been reported up to $55 \%$ of patients in 2 years. ${ }^{7}$ Prevention of chemotherapy-induced cardiomyopathy involves careful evaluation of the type and dose of oncologic regimens and the use of dexrazoxane, an ethylenediaminetetraacetic acid-like chelator that
Correspondence: Giovanni Quarta, Cardiovascular Department, Papa Giovanni XXIII Hospital, piazza OMS 1, 24127 Bergamo, Italy.

Tel.: +39.035.267.4346 - Fax: +39.035 .267 .4965$ E-mail: gquarta@asst-pg23.it

Key words: Dilated cardiomyopathy; reversible causes; prevention.

Acknowledgments: Iacopo Olivotto was supported by the Italian Ministry of Health: RF-20102313451 (Hypertrophic cardiomyopathy: new insights from deep sequencing and psychosocial evaluation), RF-2013-02356787 (Left ventricular hypertrophy in aortic valve disease and hypertrophic cardiomyopathy: genetic basis, biophysical correlates and viral therapy models), and NET2011-02347173 (Mechanisms and treatment of coronary microvascular dysfunction in patients with genetic or secondary left ventricular hypertrophy); and by Telethon Italy (GGP13162). Pier Lambiase was supported by UCLH Biomedicine NIHR.

Received for publication: 2 March 2016.

Revision received: 28 June 2016.

Accepted for publication:

This work is licensed under a Creative Commons Attribution NonCommercial 4.0 License (CC BYNC 4.0).

(C) Copyright G. Quarta et al., 2016

Licensee PAGEPress, Italy

Cardiogenetics 2016; 6:5862

doi:10.4081/cardiogenetics.2016.5862

reduces oxidative damage. In addition, preventive therapy with $\beta$-blockers (carvedilol), angiotensin-converting enzyme (ACE)inhibitors and statins may be effective, although the evidence supporting their protective role is limited. A recent meta-analysis of a small number of trials showed a relative risk reduction in risk of heart failure or LVEF decline following chemotherapy of approximately $70 \%$ for $\beta$-blockers and $90 \%$ for ACEinhibitors. ${ }^{8}$ These data support the concept that optimization of hemodynamics and neurohormonal milieu prior to anthracycline therapy may help to prevent myocyte injury. Another promising strategy for the management of LV dysfunction due to anticancer treatment relies on the use of novel, more sensitive diagnostic techniques allowing earlier recognition of myocardial damage. Most relevantly, strain echocardiography and cardiac MRI, along with biomarkers such as cardiac troponins and NTproBNP have shown the best results in terms of risk assessment for the timing of early interventions. ${ }^{1,2,4}$

To date, the pathogenesis of cardiotoxicity associated with anthracycline therapy is still poorly understood. The most commonly accepted hypothesis for anthracycline-induced car- 
diomyopathy has been the generation of excessive amount of reactive oxygen species (ROS) by electron exchange between the anthracycline quinone and oxygen molecules and/or other intracellular molecular targets. ${ }^{9}$ Other mechanisms include the formation of DNA adducts by anthracyclines emiquinone or the generation of superoxide anions by anthracycline metabolism, with subsequent cellular damage caused by superoxide anions with subsequent degradation of sarcomeric proteins, mitochondrial dysfunction and DNA damage. ${ }^{10}$ Although in vivo and in vitro studies confirmed increased ROS production in cardiomyocytes after anthracycline therapy, antioxidants and iron chelation only showed partial positive effects and none of them was able to prevent cardiomyopathy. ${ }^{11,12}$ Topoisomerase (Top) $2 \beta$ was recently revealed as the main determinant of anthracycline-induced cardiac toxicity. ${ }^{13}$ The physiological role of Top2 is to unfold DNA strands during DNA replication, transcription, or recombination. ${ }^{14}$ Anthracycline-induced production of oxygen radicals appears to be mainly due to a reduction in antioxidant enzyme gene transcription, which is also Top2 $\beta$-dependent..$^{13}$ Top2 $\beta$-inhibition also leads to impaired mitochondrial biogenesis and function. Indeed, deletion of Top $2 \beta$ gene from the heart fully protects mice from anthracycline-induced cardiomyopathy, supporting the idea that Top $2 \beta$ is the primary mediator of anthracycline-induced cardiotoxicity.

Recent studies also postulated an additional mechanism for chemotherapy-induced cardiotoxicity, which is related with the dysfunction of resident myocardial stem cells. Historically, cardiomyocytes have been considered as terminally differentiated cells, with no postnatal turnover. However, several recent studies $^{15-18}$ provided strong evidence of the presence of a cardiomyocyte turnover in the human heart controlled by a resident stem cell population. Cardiac cell turnover has been recently quantified by measuring the amount of carbon $14\left({ }^{14} \mathrm{C}\right)$ integrated into DNA of cardiomyocytes from subjects born both before and after the nuclear bomb tests. ${ }^{16}$ By fitting those measurements with an appropriate mathematical model, the calculated annual rate of cardiomyocyte renewal was $1 \%$ at 25 years of age and decreased to $0.45 \%$ at $75 .{ }^{16}$ Higher values are observed in non-cardiomyocytes myocardial cells (e.g., fibroblasts). In the normal human heart nearly 14 myocytes per million of cells are actually dividing..$^{15}$ More than 150 cardiomyocytes per million of cells are subject to apoptosis. ${ }^{19}$ Therefore, if a small fraction of cardiac myocytes is cycling, it may be sensitive to the antiproliferative action of anthracyclines. Proliferating myocytes increase in the damaged human heart (e.g., after ischemia). ${ }^{15}$ The same phenomenon may be active in anthracycline-induced cardiomy- opathy and repeated administrations of the drug will gradually reduce the population of myocyte progenitors that are activated to repair the damage, resulting in a time-dependent accumulation of cardiac injury. The high incidence of late cardiotoxicity in the pediatric oncology population may well be explained by the deleterious effects of anthracyclines on the higher fraction of proliferating cardiomyocytes typical of young hearts. ${ }^{20}$ Indeed, a higher turnover leads to an increased susceptibility to cytotoxic insult and progressive cells death in young cancer survivors. Stem cells hold the great promise of regenerative therapies such as those used for myocardial infarction. ${ }^{21}$ Recent results on rats have shown that dysfunction of cardiac stem cells occurs early after drug exposure and that doxorubicin-induced cardiomyopathy can be prevented by injection of cardiac stem cell. ${ }^{22}$

Finally, other agents such as cisplatin, 5-fluorouracil and rituximab may cause myocardial damage mediated by ischemia, whether through coronary artery spasm or endothelial impairment. Ischemia can occur in patients without underlying coronary artery disease (CAD), but the incidence is higher in patients with CAD. ${ }^{23}$

\section{Alcohol-related cardiomyopathy}

Daily consumption of low to moderate amounts of alcohol has been shown to have potent beneficial effects on the cardiovascular system. ${ }^{24,25}$ In contrast, it is known since late $19^{\text {th }}$ century that chronic exposure to high levels of alcohol for a long period could lead to progressive cardiac dysfunction and heart failure. ${ }^{24,25}$ Excessive alcohol intake is currently recognized as a common cause of dilated cardiomyopathy (DCM), and DCM due to alcohol abuse is known as alcohol-related cardiomyopathy (ACM) (Table 1, Figure 1). ${ }^{25,26}$ The evidence supporting excessive alcohol exposure as a cause of DCM includes several experimental studies, ${ }^{25}$ epidemiological studies showing higher prevalence of excessive alcohol consumption in DCM patients than in the general population, ${ }^{27}$ and echocardiographic studies in asymptomatic alcohol abusers. ${ }^{28}$

Based on experimental studies the pathophysiology of ACM includes several processes with a crucial role of apoptosis ${ }^{29}$ and excess oxidative stress. ${ }^{30}$ In addition, genetic predisposition is likely to play a major role..$^{25,31}$ Individual susceptibility to ACM is supported by the fact that only a small subset of alcohol abusers develop the disease. Prevalence of ACM in DCM series range from 23 to $47 \%$ making ACM the leading cause of DCM in western countries. ${ }^{25}$ The diagnosis of ACM is usually one of exclusion in a patient with DCM with no identified cause and a long history of heavy alcohol abuse.

Data on the amount of alcohol consumption required to cause ACM are limited and controversial in that a proportional relationship between myocardial damage and alcohol intake has not been proven. In most studies on the natural history and the long-term prognosis of ACM, an amount of $80 \mathrm{~g}$ a day (equivalent to $10 \mathrm{U}$ or 5 glasses of $12 \%$ wine or $3-4$ pints of beer) during at least 5 years was deemed sufficient to produce the disease. ${ }^{32-35}$ However, average alcohol consumption shown by the patients included in these series was much higher and consumption periods were much longer. Furthermore, the accepted definition of ACM does not take into account important factors such as body mass index (BMI) or sex. For example, women and individuals with lower BMI are significantly more susceptible to the negative effects of alcohol.

A recent study examined the contemporary natural history of ACM. ${ }^{36}$ In this study involving 94 patients evaluated at a single referral center during the period 1994-2011, approximately one third died or needed a heart transplant while another third showed persistent LV dysfunction despite lack of adverse events. The final third progressively normalized their cardiac function. In this study predictors of poor outcome (death and heart transplant) were absence of $\beta$-blocker treatment, atrial fibrillation and $\mathrm{QRS}>120 \mathrm{~ms}^{36}$

Recommended treatment in ACM does not differ from other forms of DCM and should include guideline-based anti-failure medications. ${ }^{25}$ Special attention should be paid to $\beta$ blocker treatment given its protective effect in the above mentioned study. ${ }^{36}$ Although there are no specific randomized studies examining the efficacy of implatable cardioverter defibrillators (ICDs) on ACM, a device should always be considered in patients with ACM and severely impaired systolic function, who seem to be at higher risk of malignant ventricular arrhythmias compared to other DCM patients. ${ }^{37,38}$ On the other hand, the ultimate decision regarding an ICD is challenging, because LVEF can greatly improve in the first year after diagnosis. Only one study has specifically investigated the incidence of ventricular arrhythmias in ACM. ${ }^{38}$ Investigators reported that no malignant ventricular arrhythmias were found among ACM patients if LVEF had improved to or remained $\geq 40 \%{ }^{38}$

Complete withdrawal is recommended to all patients with ACM and may lead to complete recovery of cardiac function, and three longterm studies have shown better outcomes of ACM in abstainers than in patients who maintained alcohol consumption. ${ }^{32-34}$ Nevertheless, there is controversy regarding the need for complete alcohol withdrawal in ACM. The controversy emerges from the observation that 
studies evaluating the effect of alcohol abstinence included patients who reduced alcohol intake to low/moderate levels alongside with those who stopped consuming alcohol completely. ${ }^{21-34}$ Furthermore, the only contemporary study found that prognosis and degree of LVEF recovery in ACM patients who decreased alcohol intake to moderate levels was comparably favorable to that of abstainers. ${ }^{36}$ Ultimately, complete alcohol cessation appears desirable for ACM patients giving the fact that these patients have suffered an important addiction and may find it extremely difficult to maintain low-moderate intakes over time.

Basic research studies have described several mechanisms that could be involved in determining the functional and structural alterations found in ACM, linked both to ethanol and its main metabolite, acetaldehyde. Most studies highlight abnormalities of intracellular organelles causing alterations in the energetic metabolism and calcium homeostasis, which are especially relevant for the development of contractile anomalies. The mechanisms described to date include: apoptosis, ${ }^{39}$ up-regulation of the L-type calcium channels, ${ }^{40}$ alterations of the excitation-contraction coupling in cardiac myocytes, ${ }^{41}$ structural and functional alterations of the mitochondria and sarcoplasmic reticulum,${ }^{42}$ changes in calcium sensitivity of myofilaments, ${ }^{43}$ alterations of mitochondrial oxidation, ${ }^{39}$ deregulation of protein synthesis, decrease of contractile proteins ${ }^{44}$ and activation of the renin-angiotensin system and of the sympathetic nervous system. ${ }^{45}$ To date, however, the sequence of events that occur in alcohol-induced myocardial damage are unresolved.

\section{Myocarditis}

Myocarditis (Table 1) is an inflammatory disease of the heart muscle and is defined immunohistochemically by the presence on endomyocardial biopsy of $\geq 14$ leucocytes $/ \mathrm{mm}^{2}$ including up to 4 monocytes $/ \mathrm{mm}^{2}$ - with the presence of CD3 positive T-lymphocytes $\geq 7$ cells $/ \mathrm{mm}^{2}{ }^{26}$ Myocarditis can be suspected clinically in symptomatic subjects [chest pain, pseudoischemic electrocardiographic (ECG) pattern, dyspnea, unexplained arrhythmias, cardiogenic shock] in the presence of one or

Table 2. Reversible dilated cardiomyopathies.

\begin{tabular}{|c|c|c|c|c|c|c|}
\hline Disease & Diagnosis & Etiology & Prevalence & Recovery & Prognosis & Specific therapy \\
\hline $\begin{array}{l}\text { Chemotherapy- } \\
\text { induced CMP }\end{array}$ & $\begin{array}{l}\text { A } \geq 5 \% \text { decline LVEF } \\
\text { resulting in an LVEF } \\
<55 \% \text { with symptoms } \\
\text { of heart failure, or a } \\
\geq 10 \% \text { decline to result } \\
\text { in an LVEF }<55 \% \\
\text { without symptoms } \\
\text { of heart failure } 1,3\end{array}$ & $\begin{array}{l}\text { - ROS generation } \\
\text { - Formation of DNA adducts } \\
\text { - Top2 } \beta \text { inhibition } \\
\text { - Dysfunction of resident } \\
\text { myocardial stem cells } \\
\text { - Ischemia (cisplatin, } \\
\text { 5-fluorouracil } \\
\text { and rituximab) }\end{array}$ & $\begin{array}{l}3-26 \% \text { of } \\
\text { patients undergoing } \\
\text { chemotherapy }^{1}\end{array}$ & $\begin{array}{l}\text { Up } 55 \% \text { in } \\
2 \text { years }^{7}\end{array}$ & $\begin{array}{l}\text { - Poor for type } \\
\text { I cardiotoxicity: 60\% } \\
\text { mortality at 2-3 } \\
\text { years for doxorubicin, } \\
\text { up to 40\% for } \\
\text { cyclophosphamide } \\
\text { - Low mortality for type } \\
\text { II cardiotoxicity: } \\
\text { 2.5\% of all heart } \\
\text { transplant }{ }^{6}\end{array}$ & $\begin{array}{l}\text { - Reduce dose/ } \\
\text { discontinuation of the } \\
\text { chemotherapic agent } \\
\text { - Earlier detection } \\
\text { of myocardial damage } \\
\text { (strain echocardiography, } \\
\text { CMR, proBNP, etc.) } \\
\text { - Dexrazoxane (debated) } \\
\text { - } \beta \text {-blockers, } \\
\text { ACE-inhibitors } \\
\text { and statins (debated) } \\
\text { - Stem cell therapy } \\
\text { (experimental) }\end{array}$ \\
\hline Alcohol-related CMP & $\begin{array}{l}\text { Dilatation and } \\
\text { impaired } \\
\text { contraction } \\
\text { of the left ventricle } \\
\text { or both ventricles } \\
\text { related to excessive } \\
\text { alcohol intake }\end{array}$ & $\begin{array}{l}80 \text { g a day of } \\
\text { alcohol intake } \\
\text { (equivalent } \\
\text { To } 10 \mathrm{U} \text { or } 5 \\
\text { glasses of } 12 \% \\
\text { wine or } 3-4 \text { pints } \\
\text { of beer) for at } \\
\text { least } 5 \text { years }\end{array}$ & $\begin{array}{l}\text { Up to } 40 \% \text { of } \\
\text { DCM pts in } \\
\text { western } \\
\text { countries }^{36}\end{array}$ & $\begin{array}{l}37 \% \text { at } 4 \text { years } \\
\text { from } \\
\text { diagnosis }\end{array}$ & $\begin{array}{l}\text { At } 4 \text { years from } \\
\text { diagnosis, } \\
30 \% \text { dies or } \\
\text { needs a heart } \\
\text { transplant, } 33 \% \\
\text { shows persistent } \\
\text { LV dysfunction }{ }^{36}\end{array}$ & $\begin{array}{l}\text { - Complete alcohol } \\
\text { withdrawal } \\
\text { - Standard anti-failure } \\
\text { medications, } \\
\text { with special priority } \\
\text { to } \beta \text {-blockers }\end{array}$ \\
\hline Myocarditis & $\begin{array}{l}\text { Inflammatory } \\
\text { disease of the } \\
\text { heart muscle } \\
\text { on EMB: } \\
\geq 14 \text { leucocytes } / \mathrm{mm}^{2} \text { - } \\
\text { including up to } 4 \\
\text { monocytes } / \mathrm{mm}^{2} \text { - } \\
\text { with the presence } \\
\text { of CD3 positive } \\
\text { T-lymphocytes } \\
\geq 7 \text { cells } / \mathrm{mm}^{2}{ }^{46}\end{array}$ & $\begin{array}{l}\text { - Viral infections } \\
\text { (PVB19, HHV6, } \\
\text { enterovirus, } \\
\text { adenovirus, } \\
\text { influenza A virus, } \\
\text { EBV, CMV, } \\
\text { HCV, HIV) } \\
\text { - Other infectious } \\
\text { agents (bacterial, } \\
\text { fungal, protozoal) } \\
\text { - Immuno-mediated } \\
\text { toxic agents }\end{array}$ & $\begin{array}{l}9-16 \% \text { of DCM } \\
\text { adult patients }\end{array}$ & $\begin{array}{l}\text { - } 50 \% \\
\text { non-fulminant } \\
\text { acute } \\
\text { myocarditis }{ }^{46} \\
\text { - Up to } 90 \% \text { of } \\
\text { fulminant } \\
\text { myocarditis } 56\end{array}$ & $\begin{array}{l}\text { At } 11 \text { years follow } \\
\text { up } 93 \% \text { of fulminant } \\
\text { myocarditis pts alive } \\
\text { compared to } 45 \% \\
\text { of acute } \\
\text { myocarditis pts }{ }^{57}\end{array}$ & $\begin{array}{l}\text { Antiviral agents } \\
\text { (interferon), } \\
\text { immunosuppression } \\
\text { (azathioprine, cortisone), } \\
\text { immunomodulation } \\
\text { (intravenous } \\
\text { immunoglobulin) } \\
\text { (debated and } \\
\text { controversial) }\end{array}$ \\
\hline Peri-partum CMP & $\begin{array}{l}\text { LVEF }<45 \% \text { or FS } \\
<30 \% \text { or both }{ }^{58} \\
\text { presenting } \\
\text { with signs } \\
\text { of cardiac } \\
\text { failure during } \\
\text { the last month } \\
\text { of pregnancy or } \\
\text { within } 5 \text { months } \\
\text { of delivery }{ }^{26}\end{array}$ & $\begin{array}{l}\text { - Viral myocarditis } \\
\text { - Auto-immunity } \\
\text { - Inflammation } \\
\text { - Increased oxidative } \\
\text { stress and apoptosis } \\
\text { - Malnutrition } \\
\text { - Prolactin } \\
\text { - Hemodynamic stress } \\
\text { - Genetic milieu } \\
\text { (Titin gene) }\end{array}$ & $\begin{array}{l}\text { 1:4000 to } \\
\text { 1:1000 } \\
\text { live births } \\
\text { in the Western } \\
\text { World }{ }^{60,61}\end{array}$ & $\begin{array}{l}\text { Up to } 65 \% \\
\text { of patients } \\
\text { within } 6 \text { months } \\
\text { of delivery } 62\end{array}$ & $\begin{array}{l}\text { - If dilation and } \\
\text { systolic dysfunction } \\
\text { persist, the prognosis } \\
\text { is poor } \\
\text { - If there is full } \\
\text { recovery within } \\
6 \text { months from } \\
\text { delivery, the prognosis } \\
\text { is excellent }\end{array}$ & $\begin{array}{l}\text { - Avoid all teratogenic } \\
\text { drugs if pregnancy/ } \\
\text { lactation is ongoing, } \\
\text { including } \\
\text { ACE-inhibitors } \\
\text { and ARBs } \\
\text { - Bromocriptine (debated) } \\
\text { - Pentoxifylline } \\
\text { (debated) }\end{array}$ \\
\hline
\end{tabular}

CMP, cardiomyopathy; LVEF, left ventricular ejection fraction; ROS, reactive oxidative species; CMR, cardiovascular magnetic resonance; ACE-inhibitors, angiotensin-converting enzyme inhibitors; DCM, dilated cardiomyopathy; EMB, endomyocardial biopsy; PVB19, parvovirus B19; HHV6, human herpesvirus 6; EBV, Epstein-Barr virus; CMV, citomegalovirus; HCV, hepatitis C virus; HIV, human immunodeficiency virus; FS, fractional shortening; ARBs, angiotensin II receptor blockers. 
more diagnostic criteria: ECG and/or Holter monitoring abnormalities (brady- and tachyarrhythmias), elevated cardiac enzymes, functional and structural abnormalities detected by cardiac imaging including tissue abnormalities detected by CMR. The diagnosis can also be suspected in asymptomatic subjects when two or more diagnostic criteria from different categories are met. Estimated incidence vovirus B19 (PVB19), human herpesvirus 6, enterovirus, adenovirus, influenza A virus, Epstein-Barr virus, citomegalovirus, hepatitis C virus, human immunodeficiency virus] are the most common cause of myocarditis, followed by other infectious agents (bacterial, fungal, protozoal, etc.), immuno-mediated causes and toxic agents. Using polymerase chain reaction technology, viral RNA or DNA is commonly identified within the myocardium of affected patients. ${ }^{48}$ Extensive studies performed in biopsy and autopsy myocardial specimens have linked specific viral infections with up to $69 \%$ of cases of clinical myocarditis. ${ }^{49}$ Moreover, elevated serum levels of antibodies against specific viruses have been detected in patients with idiopathic dilated cardiomyopathy. ${ }^{50}$ is $22 / 100,000 /$ year. ${ }^{47}$ Viral infections [par-

Little is known about the early stages of acute viral myocarditis in patients. Enteroviruses (e.g., Coxsackie-B viruses) are responsible for one quarter of cases $^{49}$ and their mechanism of damage to the myocardium has been well characterized in animal models. Enteroviruses gain access to the host via the gastrointestinal or respiratory tracts, the heart being a secondary target. Myocardial infection occurs in 3 subsequent phases: i) viral entry into cardiomyocytes and activation of innate immunity; ii) viral replication and activation of acquired immune responses; iii) resolution with recovery or development of chronic dilated cardiomyopathy. Initial viral entry is mediated by a specific cell-surface receptor. Enteroviruses and adenoviruses recognize a common transmembrane receptor on cardiomyocytes, the coxsackievirus and adenovirus receptor. ${ }^{51,52}$ This is essential for the initiation of the infection ${ }^{53}$ and subsequent viral replication leading to myocyte necrosis. ${ }^{54}$ Natural killer cells, macrophages, and T lymphocytes migrate towards the infection site, causing additional myocardial injury. The latter starts the second phase, where autoimmune reactions activate $\mathrm{T}$ cells that target host myocardium. High levels of cytokines are liber-

\section{Pre}
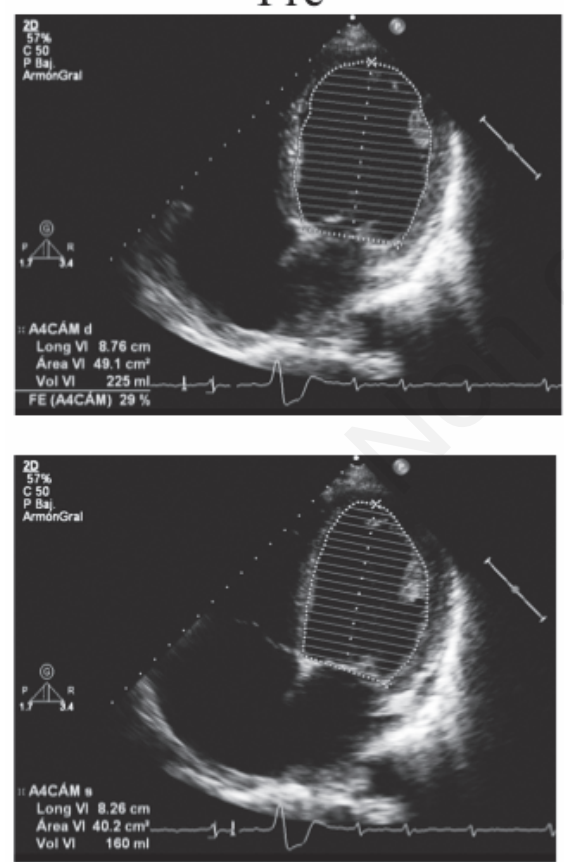
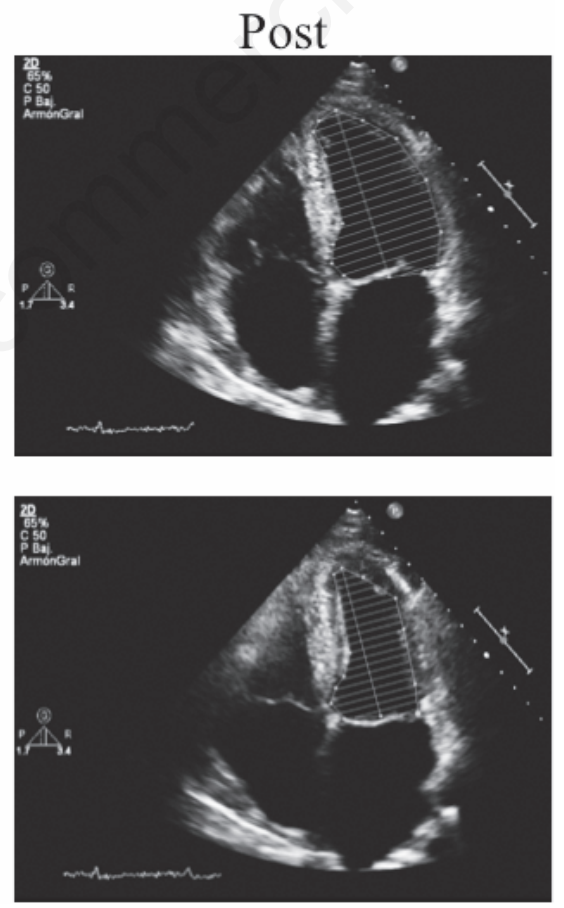

Figure 1. Echo still frame images (diastole top panels, systole bottom panels) from a 52year old male admitted for acute heart failure and past medical history including hypertension, atrial fibrillation and consumption of $100 \mathrm{~g}$ of alcohol per day for more than 20 years and normal coronary arteries. An echocardiogram (left panels) showed a very dilated left ventricle (LV), with $L V$ ejection fraction $<25 \%$ and right ventricular (RV) mild to moderate systolic dysfunction. An echocardiogram performed 6 years after first evaluation (right panels), after standard heart failure medication and complete alcohol intake withdrawal, shows normal LV and RV size and function.

ated during which can further potentiate cardiomyocyte damage and reduce contractile function. Phase 2 (the subacute phase) can last weeks to months; in most patients, ventricular contractile function improve as the amount of replicating viruses diminishes. However, the cardiomyopathy may enter a chronic phase, which becomes irreversible.

Other viruses cause myocarditis by different mechanisms. PVB19 can hibernate after a primary infection in childhood and later infect the cardiac endothelium. PVB19 genomes have been found in cardiac endothelial cells in patients with fulminant myocarditis. ${ }^{55}$ Though not directly infecting cardiomyocytes, the virus exerts its pathogenic effects by local activation of cytokines [tumor necrosis factor $\alpha$ (TNF- $\alpha$ ) and interleukin-6 (IL-6)] and induction of endothelial apoptosis. Endothelial damage may in turn compromise tissue perfusion, causing myocardial ischemia. Moreover, accumulation of lymphocytes in the coronary microcirculation leads to a sustained rise in coronary resistance, contributing to myocyte necrosis.

Although myocarditis is an acquired disease, genetic polymorphisms may facilitate viral infection and direct cellular damage and may play a role in subsequent immuno-mediated injury. In addition, genetically determined DCM may represent a preferential substrate for myocarditis. Clinical presentation may be: i) fulminant (lymphocytic, giant cell myocarditis), which can rapidly evolve towards cardiogenic shock and death, but may resolve completely in survivors; ii) acute, which often resolves completely; and iii) chronic active myocarditis, characterized by ongoing inflammation and damage leading to DCM.

Complete recovery of LV function occurs in about $50 \%$ of patients with non-fulminant acute myocarditis ${ }^{46}$ and up to $90 \%$ of patients with fulminant myocarditis. ${ }^{56}$ In one study, at 11 years follow up $93 \%$ of fulminant myocarditis patients were alive compared to $45 \%$ of patients with acute myocarditis. ${ }^{57}$ Supportive and standard anti-failure medications are still the cornerstone of treatment. The evidence favoring specific therapy with antiviral agents (for example interferon), immunosuppression (azathioprine, cortisone), immunomodulation (intravenous immunoglobulin) is still based on small studies ${ }^{46}$ and controversial. It is unclear why some patients have full recovery and others have persistent LV dysfunction. In addition, it is not clear how long heart failure treatment is needed after normalization of LV function. Finally, it is still controversial whether family screening should be considered, as evidence of myocardits does not exclude genetically determined DCM or - in patients presenting with sudden cardiac death - a channellopathy. 


\section{Peripartum cardiomyopathy}

Peripartum cardiomyopathy (PPCMP) (Table 1) is an increasingly recognized entity characterized by LV dysfunction (defined as LV ejection fraction $<45 \%$ or fractional shortening $<30 \%$ or both ${ }^{58}$ presenting with signs of cardiac failure during the last month of pregnancy or within 5 months of delivery, ${ }^{26}$ where no other cause of heart failure is found. LV function tends to recover in the majority of cases within 6-12 months. Duration of standard antifailure medication after normalization of LV function is unknown. The risk of PPCMP with subsequent pregnancies, although still uncertain, depends on recovery of LV function, and has been described in up to $50 \%$ of patients with persistent dysfunction compared to $20 \%$ in patients with LVEF normalization.59 The mechanism of relapse remains unclear and it is unknown whether preventive measure can be implemented in patients with prior history of PPCMP undergoing a new pregnancy.

The prevalence of PPCMP has been estimated to be 1:4000 to $1: 1000$ live births in the Western world. ${ }^{60,61}$ Advanced maternity age, race (African), twin gestation, multiparity, gestational hypertension, chronic hypertension, preeclampsia, prolonged use of tocolytics are known risk factors for PPCMP. ${ }^{62}$ The etiology remains largely unknown. Viral myocardits, auto-immunity, inflammation, increased oxidative stress and apoptosis, genetic predisposition, malnutrition, prolactin and hemodynamic stress have all been proposed as pathogenetic or contributing mechanisms. Familial occurrence of PPCMP has been described and genetic association has been shown in mice and humans. ${ }^{63,64}$ Recently, a large study on 172 PPCMP patients, showed a prevalence of truncating variants (especially in the Titin gene) similar to DCM patients, suggesting that these variants may predispose to the condition. ${ }^{65}$

Myocarditis appears to be the main pathophysiological mechanism in PPCMP. A 76\% incidence of myocarditis at myocardial biopsy was reported in a study on a large number of patients with PPCMP. ${ }^{66}$ Inflammatory cytokines have also been named as possible leading causative factors for PPCMP. In patients with PPCMP, some studies found elevated plasma levels of cytokines, such as TNF- $\alpha$ and IL-6, as well as Fas/APO-1 (a apoptosis-signaling surface receptor).$^{67}$ Cytokines may lead to PPCMP through initiation of an inflammatory cascade when they come in contact with fetal cells that have reached the maternal circulation during delivery. These cells may have initially escaped the maternal immune system because of the immunosuppressive state of pregnancy. These cells are therefore able to settle in various organs, including cardiac tissue, leading to an autoimmune trigger when the maternal immune system effectiveness is restored shortly after delivery. ${ }^{68}$ The hemodynamic stress associated with pregnancy (increased preload and decreased afterload) has been shown to cause LV remodeling and hypertrophy. ${ }^{69}$ The physiological reduction in LV systolic function brought on by the reverseremodeling process after delivery may be more exaggerated in subjects with peripartum cardiomyopathy. Animal studies supported the role of prolactin in peripartum cardiomyopathy. Decreased levels of myocardial signal transduction lead via catabolism of prolactin to an antiangiogenic and proapoptotic isoform of the hormone in the heart, which may cause PPCMP. ${ }^{70}$ Of note, these results have been confirmed in patients, supporting a specific antiprolactin therapeutic strategy.

Recovery of LV systolic function has been reported in up to $65 \%$ of patients within 6 months of delivery. ${ }^{62}$ Management of PPCMP includes standard heart failure regimen, but careful consideration must be made to avoid all teratogenic drugs if the pregnancy is ongoing, including angiotensin-converting enzyme inhibitors and angiotensin-receptor blockers. Hydralazine and nitrates may be safely used as alternative therapies. $\beta$-adrenoceptor blockers may also be used during pregnancy. Immunosuppressive agents and immunoglobulins may be considered in patients with biopsy-proven myocarditis that have not improved after two weeks of standard heart failure therapy ${ }^{66,71}$ Bromocriptine, which inhibits prolactin secretion, has been shown to promote recovery of $\mathrm{LV}$ function in a small PPCMP cohort, ${ }^{72}$ but safety issues have limited its use in clinical practice. ${ }^{73}$ The anti-inflammatory agent pentoxifylline has been investigated in a small trial ${ }^{74}$ and shown to be effective, but further evidence is required.

\section{Clinical perspective}

The diverse forms of dilated cardiomyopathy associated with a potential for recovery of LV dysfunction share a number of features. The etiology may be uncertain and a specific diagnosis may be often difficult. An history of stressful events may lack in Tako-Tsubo cardiomyopathy, the role of concomitant tachyarrhythmias may be unclear in tachycardiainduced cardiomyopathy (TIC), patients may have had chemotherapy in the past with dubious impact on later occurrence of LV dysfunction, the amount of alcohol consumption may be difficult to ascertain and DCM found during pregnancy may be pre-existing. Sometimes, more than a possible cause is found, and all these conditions may represent acquired disease sponsored by genetic predisposition or unmask true genetic DCM, which should prompt family screening. The molecular mechanisms underlying these conditions are often unclear and it is still unknown how long heart failure treatment needs to be continued once LV function has recovered and whether primary or secondary prevention is possible, for example before starting a potential cardiotoxic chemotherapy or planning a new pregnancy. Specific treatments are emerging for some conditions (e.g., peripartum cardiomyopathy or autoimmune myocarditis), but still based on small studies. In all these forms, early recognition appears a cornerstone for clinical management, before permanent ultrastructural and structural damage occur, in order to improve likelihood of recovery. For example, recognizing TIC is fundamental as LV dysfunction may be completely reversible once tachycardia has been controlled, even though it may have been so severe as to be considered for transplantation. ${ }^{75}$ It is also important to note that a significant minority of cases of dilated cardiomyopathy recover even in absence of reversible factors. Finally, these conditions represent paradigms of cardiac recovery suggesting a number of molecular mechanisms, which might be exploited in other cardiac conditions that are at present progressive and unresponsive to therapy. The identification of pathways to recovery also shows the way for novel therapeutic targets ultimately benefitting all cardiac patients. However, the road ahead towards definite evidence and practical application remains long and winding.

\section{References}

1. $\mathrm{Yu}$ AF, Steingart RM, Fuster V. Cardiomyopathy associated with cancer therapy. J Card Fail 2014;20:841-52.

2. Plana JC, Galderisi M, Barac A, et al. Expert consensus for multimodality imaging evaluation of adult patients during and after cancer therapy: a report from the American Society of Echocardiography and the European Association of Cardiovascular Imaging. Eur Heart J Cardiovasc Imaging 2014;15:1063-93.

3. Seidman A, Hudis C, Pierri MK, et al. Cardiac dysfunction in the trastuzumab clinical trials experience. J Clin Oncol 2002;20:1215-21.

4. Khouri MG, Douglas PS, Mackey JR, et al. Cancer therapy-induced cardiac toxicity in early breast cancer: addressing the unresolved issues. Circulation 2012;126:2749-63.

5. Nolan MT, Lowenthal RM, Venn A, Marwick TH. Chemotherapy-related cardiomyopathy: a neglected aspect of cancer survivorship. Intern Med J 2014;44:939-50.

6. Mukku RB, Fonarow GC, Watson KE, et al. Heart failure therapies for end-stage 
chemotherapy-induced cardiomyopathy. J Card Fail 2016;22:439-48.

7. Cardinale D, Colombo A, Lamantia G, et al. Anthracycline-induced cardiomyopathy: clinical relevance and response to pharmacologic therapy. J Am Coll Cardiol 2010; 55:213-20.

8. Kalam K, Marwick TH. Role of cardioprotective therapy for prevention of cardiotoxicity with chemotherapy: a systematic review and meta-analysis. Eur J Cancer 2013;49:2900-9.

9. Doroshow JH. Effect of anthracycline antibiotics on oxygen radical formation in rat heart. Cancer Res 1983;43:460-72.

10. L'Ecuyer T, Sanjeev S, Thomas R, et al. DNA damage is an early event in doxorubicin-induced cardiac myocyte death. Am J Physiol Heart Circ Physiol 2006;291: H1273-80.

11. Dresdale AR, Barr LH, Bonow RO, et al. Prospective randomized study of the role of $\mathrm{N}$-acetyl cysteine in reversing doxorubicin-induced cardiomyopathy. Am J Clin Oncol 1982;5:657-63.

12. Hasinoff BB, Patel D, Wu X. The oral iron chelator ICL670A (deferasirox) does not protect myocytes against doxorubicin. Free Radic Biol Med 2003;35:1469-79.

13. Zhang S, Liu X, Bawa-Khalfe T, et al. Identification of the molecular basis of doxorubicin-induced cardiotoxicity. Nat Med 2012;18:1639-42.

14. Liu LF, Wang JC. Supercoiling of the DNA template during transcription. Proc Natl Acad Sci U S A 1987;84:7024-7.

15. Urbanek K, Quaini F, Tasca G, et al. Intense myocyte formation from cardiac stem cells in human cardiac hypertrophy. Proc Natl Acad Sci U S A 2003;100:10440-5.

16. Bergmann 0, Bhardwaj RD, Bernard S, et al. Evidence for cardiomyocyte renewal in humans. Science. 2009;324:98-102.

17. Urbanek K, Torella D, Sheikh F, et al. Myocardial regeneration by activation of multipotent cardiac stem cells in ischemic heart failure. Proc Natl Acad Sci U S A 2005;102:8692-7.

18. Oh H, Bradfute SB, Gallardo TD, et al. Cardiac progenitor cells from adult myocardium: homing, differentiation, and fusion after infarction. Proc Natl Acad Sci U S A 2003;100:12313-8.

19. Olivetti G, Abbi R, Quaini F, et al. Apoptosis in the failing human heart. $\mathrm{N}$ Engl $\mathrm{J}$ Med 1997;336:1131-41.

20. Amir G, Ma X, Reddy VM, et al. Dynamics of human myocardial progenitor cell populations in the neonatal period. Ann Thorac Surg 2008;86:1311-9.

21. Menasche P. Cell-based therapy for heart disease: a clinically oriented perspective. Mol Ther 2009;17:758-66.

22. De Angelis A, Piegari E, Cappetta D, et al.
Anthracycline cardiomyopathy is mediated by depletion of the cardiac stem cell pool and is rescued by restoration of progenitor cell function. Circulation 2010;121:276-92.

23. Yeh ET, Tong AT, Lenihan DJ, et al. Cardiovascular complications of cancer therapy: diagnosis, pathogenesis, and management. Circulation 2004;109:3122-31.

24. Bryson CL, Mukamal KJ, Mittleman MA, et al. The association of alcohol consumption and incident heart failure: the Cardiovascular Health Study. J Am Coll Cardiol 2006;48:305-11.

25. Guzzo-Merello G, Cobo-Marcos M, GallegoDelgado M, Garcia-Pavia P. Alcoholic cardiomyopathy. World J Cardiol 2014;6:771-81.

26. Elliott P, Andersson B, Arbustini E, et al. Classification of the cardiomyopathies: a position statement from the European Society of Cardiology Working Group on Myocardial and Pericardial Diseases. Eur Heart J 2008;29:270-6.

27. McKenna CJ, Codd MB, McCann HA, Sugrue DD. Alcohol consumption and idiopathic dilated cardiomyopathy: a case control study. Am Heart J 1998;135:833-7.

28. Fernandez-Sola J, Estruch R, Nicolas JM, et al. Comparison of alcoholic cardiomyopathy in women versus men. Am J Cardiol 1997;80:481-5.

29. Chen DB, Wang L, Wang PH. Insulin-like growth factor I retards apoptotic signaling induced by ethanol in cardiomyocytes. Life Sci 2000;67:1683-93.

30. Amici A, Levine RL, Tsai L, Stadtman ER. Conversion of amino acid residues in proteins and amino acid homopolymers to carbonyl derivatives by metal-catalyzed oxidation reactions. J Biol Chem 1989;264: 3341-6.

31. Fernandez-Sola J, Nicolas JM, Oriola J, et al. Angiotensin-converting enzyme gene polymorphism is associated with vulnerability to alcoholic cardiomyopathy. Ann Intern Med 2002;137:321-6.

32. Haissaguerre M, Fleury B, Gueguen A, et al. Mortality of dilated myocardiopathies as a function of continuation of alcohol drinking. Multivariate analysis concerning 236 patients. Presse Med 1989;18:711-4.

33. Gavazzi A, De Maria R, Parolini M, Porcu M. Alcohol abuse and dilated cardiomyopathy in men. Am J Cardiol 2000;85:1114-8.

34. Fauchier L, Babuty D, Poret P, et al. Comparison of long-term outcome of alcoholic and idiopathic dilated cardiomyopathy. Eur Heart J 2000;21:306-14.

35. Prazak P, Pfisterer M, Osswald S, et al. Differences of disease progression in congestive heart failure due to alcoholic as compared to idiopathic dilated cardiomyopathy. Eur Heart J 1996;17:251-7.

36. Guzzo-Merello G, Segovia J, Dominguez F, et al. Natural history and prognostic fac- tors in alcoholic cardiomyopathy. JACC Heart Fail 2015;3:78-86.

37. George A, Figueredo VM. Alcohol and arrhythmias: a comprehensive review. J Cardiovasc Med (Hagerstown) 2010;11: 221-8.

38. Guzzo-Merello G, Dominguez F, GonzalezLopez E, et al. Ventricular arrhythmias in alcoholic cardiomyopathy. Int $\mathrm{J}$ Cardiol 2015;199:99-105.

39. Chen DB, Wang L, Wang PH. Insulin-like growth factor I retards apoptotic signaling induced by ethanol in cardiomyocytes. Life Sci 2000;67:1683-93.

40. Guppy LJ, Littleton JM. Effect of calcium, Bay $\mathrm{K}$ 8644, and reduced perfusionon basic indices of myocardial function in isolated hearts from rats after prolonged exposure to ethanol. J Cardiovasc Pharmacol 1999;34:480-7.

41. Danziger RS, Sakai M, Capogrossi MC, et al. Ethanol acutely and reversibly suppresses excitation-contraction coupling in cardiac myocytes. Circ Res 1991;68:1660-8.

42. Hibbs RG, Ferrans VJ, Black WC, et al. Alcoholic cardiomyopathy; an electron microscopic study. Am Heart J 1965;69: 766-79.

43. Figueredo VM, Chang KC, Baker AJ, Camacho SA. Chronic alcohol-induced changes in cardiac contractility are not due to changes in the cytosolic $\mathrm{Ca} 2+$ transient. Am J Physiol 1998;275:H122-30.

44. Preedy VR, Patel VB, Why HJ, et al. Alcohol and the heart: biochemical alterations. Cardiovasc Res 1996;31:139-47.

45. Cheng CP, Cheng HJ, Cunningham C, et al. Angiotensin II type 1 receptor blockade prevents alcoholic cardiomyopathy. Circulation 2006;114:226-36.

46. Caforio AL, Pankuweit S, Arbustini E, et al. Current state of knowledge on aetiology, diagnosis, management, and therapy of myocarditis: a position statement of the European Society of Cardiology Working Group on Myocardial and Pericardial Diseases. Eur Heart J 2013;34:2636-48.

47. Global Burden of Disease Study 2013 Collaborators. Global, regional, and national incidence, prevalence, and years lived with disability for 301 acute and chronic diseases and injuries in 188 countries, 1990-2013: a systematic analysis for the Global Burden of Disease Study 2013. Lancet 2015;386:743-800.

48. Pollack A, Kontorovich AR, Fuster V, Dec GW. Viral myocarditis-diagnosis, treatment options, and current controversies. Nat Rev Cardiol 2015;12:670-80.

49. Fairley CK, Ryan M, Wall PG, Weinberg J. The organisms reported to cause infective myocarditis and pericarditis in England and Wales. J Infect 1996;32:223-5.

50. Kawai C. Idiopathic cardiomyopathy. A 
study on the infectious-immune theory as a cause of the disease. Jpn Circ J 1971;35: 765-70.

51. Freimuth P, Philipson L, Carson SD. The coxsackievirus and adenovirus receptor. Curr Top Microbiol Immunol 2008;323:6787.

52. Pinkert S, Westermann D, Wang X, et al. Prevention of cardiac dysfunction in acute coxsackievirus B3 cardiomyopathy by inducible expression of a soluble coxsackievirus-adenovirus receptor. Circulation 2009;120:2358-66.

53. Shi Y, Chen C, Lisewski U, et al. Cardiac deletion of the Coxsackievirus-adenovirus receptor abolishes Coxsackievirus B3 infection and prevents myocarditis in vivo. J Am Coll Cardiol 2009;53:1219-26.

54. Kandolf R, Ameis D, Kirschner P, et al. In situ detection of enteroviral genomes in myocardial cells by nucleic acid hybridization: an approach to the diagnosis of viral heart disease. Proc Natl Acad Sci U S A 1987;84:6272-6.

55. Bültmann BD, Klingel K, Sotlar K, et al. Fatal parvovirus B19-associated myocarditis clinically mimicking ischemic heart disease: an endothelial cell-mediated disease. Hum Pathol 2003;34:92-5.

56. Gupta S, Markham DW, Drazner MH, Mammen PP. Fulminant myocarditis. Nat Clin Pract Cardiovasc Med 2008;5:693-706.

57. McCarthy RE 3rd, Boehmer JP, Hruban RH, et al. Long-term outcome of fulminant myocarditis as compared with acute (nonfulminant) myocarditis. N Engl J Med 2000;342:690-5.

58. Hibbard JU, Lindheimer M, Lang RM. A modified definition for peripartum car- diomyopathy and prognosis based on echocardiography. Obstet Gynecol 1999; 94:311-6.

59. Elkayam U. Risk of subsequent pregnancy in women with a history of peripartum cardiomyopathy. J Am Coll Cardiol 2014;64: 1629-36.

60. Elkayam U. Clinical characteristics of peripartum cardiomyopathy in the United States: diagnosis, prognosis, and management. J Am Coll Cardiol 2011;58:659-70.

61. Kolte D, Khera S, Aronow WS, et al. Temporal trends in incidence and outcomes of peripartum cardiomyopathy in the United States: a nationwide population-based study. J Am Heart Assoc 2014;3:e001056.

62. Fett JD. Peripartum cardiomyopathy: A puzzle closer to solution. World J Cardiol 2014;6:87-99.

63. Cemin R, Janardhanan R, Donazzan L, Daves M. Peripartum cardiomyopathy: moving towards a more central role of genetics. Curr Cardiol Rev 2013;9:179-84.

64. Horne BD, Rasmusson KD, Alharethi R, et al. Genome-wide significance and replication of the chromosome 12p11.22 locus near the PTHLH gene for peripartum cardiomyopathy. Circ Cardiovasc Genet 2011;4:359-66.

65. Ware JS, Li J, Mazaika E, Yasso CM, et al. Shared genetic predisposition in peripartum and dilated cardiomyopathies. N Engl J Med 2016;374:233-41.

66. Midei MG, DeMent SH, Feldman AM, et al. Peripartum myocarditis and cardiomyopathy. Circulation 1990;81:922-8.

67. Sliwa K, Skudicky D, Bergemann A, et al. Peripartum cardiomyopathy: analysis of clinical outcome, left ventricular function, plasma levels of cytokines and Fas/APO-1. J Am Coll Cardiol 2000;35:701-5.

68. Pearson GD, Veille JC, Rahimtoola S, et al. Peripartum cardiomyopathy: National Heart, Lung, and Blood Institute and Office of Rare Diseases (National Institutes of Health) workshop recommendations and review. JAMA 2000;283:1183-8.

69. Geva T, Mauer MB, Striker L, et al. Effects of physiologic load of pregnancy on left ventricular contractility and remodeling. Am Heart J 1997;133:53-9.

70. Hilfiker-Kleiner D, Kaminski K, Podewski $\mathrm{E}$, et al. A cathepsin D-cleaved $16 \mathrm{kDa}$ form of prolactin mediates postpartum cardiomyopathy. Cell 2007;128:589-600.

71. Bozkurt B, Villaneuva FS, Holubkov R, et al. Intravenous immune globulin in the therapy of peripartum cardiomyopathy. J Am Coll Cardiol 1999;34:177-80.

72. Sliwa K, Blauwet L, Tibazarwa K, et al. Evaluation of bromocriptine in the treatment of acute severe peripartum cardiomyopathy: a proof-of-concept pilot study. Circulation 2010;121:1465-73.

73. Garg J, Palaniswamy C, Lanier GM. Peripartum cardiomyopathy: definition, incidence, etiopathogenesis, diagnosis, and management. Cardiol Rev 2015;23:69-78.

74. Sliwa K, Skudicky D, Candy G, et al. The addition of pentoxifylline to conventional therapy improves outcome in patients with peripartum cardiomyopathy. Eur J Heart Fail 2002;4:305-9.

75. Gopinathannair R, Sullivan R, Olshansky B. Tachycardia-mediated cardiomyopathy: recognition and management. Curr Heart Fail Rep 2009;6:257-64. 